\title{
Reguły św. Bazylego Wielkiego
}

\author{
Pietrow Piotr \\ pietrowpiotr@gmail.com
}

Pietrow Piotr, The Rule of Saint Basil the Great, Elpis, 16 2014: 119-126.

\begin{abstract}
The rules of monasticism were collected and published in a single work entitled Asketikon by Saint Basil the Great. It is arranged in the form of questions and answers to create one coherent work. It has two different publications.

The first publication named The Small Asketikon dates to 370-370. It is the fruit of the Saint's work among Pontic communities and consists of 203 questions and answers. The orignial Greek manuscript has not survived and it is available only in two translations: the Latin Rufin and fragments in Syrian language.

The second publication named The Great Asketikon appeard in about 377 and presents the most mature step of cenobitic monasticism in Basil's elaboration. The Great Asketikon was created by adding new questions to The Small Asketikon and consists of two parts called the The Longer Rules and The Shorter Rules.

The Longer Rules are primarily a set of questions and answers. It includes a wide range of rules and norms of the overall life in community. It refers to the fundamental rules of spirituality, such as love, sacrifice, obedience and rudimental problems connected with community organization, cenobitic monasticism and the role of the superior, work and prayer.

The second part of The Great Asketikon consists of shorter rules. Two publications are known: the first one originated in Pont and includes 286 questions and answers and second arose in Cezarei and includes 318 questions and answers. In this work, the Hierarch explains in detail issues regarding community life and solves difficult problems connected with conscience. He writes about behavior towards brothers and explains the significance of weaknesses and virtues.
\end{abstract}

\begin{abstract}
Streszczenie: Św. Bazyli Wielki zebrał i opublikował reguły życia monastycznego w jednym dziele, które nosi nazwę Asketikon. Został on ułożony w formie pytań i odpowiedzi, tak aby stworzyć jedno zwarte dzieło. Posiada on dwa różne wydania.

Pierwsze nosi nazwę Małego Asketikonu i powstało na przełomie 360 i 370 r. Było ono owocem pracy świętego wśród pontyjskich wspólnot i zawiera 203 pytania i odpowiedzi. Do dzisiejszych czasów nie zachował się żaden rękopis grecki a jedynie dwa jego przekłady: łaciński Rufina i fragmenty w języku syryjskim.

Drugie wydanie z kolei, nosi nazwę Wielkiego Asketikonu i ukazało się około 377 r. przedstawia ono najbardziej dojrzały etap cenobityzmu w opracowaniu Bazylego. Wielki Asketikon powstał w wyniku wzbogacenia Małego Asketikonu o nowe pytania i złożony jest z dwóch części nazywanych regułami dłuższymi i krótszymi .

Reguły dłuższe stanowią pierwszą serię pytań i odpowiedzi. Zawiera jej obszerny wykład zasad i norm ogólnego życia we wspólnocie. Dotyczy on podstawowych zasad duchowości, takich jak: miłości, wyrzeczeń, posłuszeństwa oraz podstawowych problemów związanych z organizacją wspólnoty np.: kryteriów przyjęć do wspólnoty, cenobityzmu, roli przełożonego, pracy i modlitwy.

Reguły krótsze stanowią drugą część Wielkiego Asketikonu. Znane są jego dwa wydania: pierwsze pochodzące z Pontu, które zawiera 286 pytań oraz drugie pochodzące z Cezarei składające się z 318 pytań i odpowiedzi. Hierarcha w tym dziele wyjaśnia szczegółowo kwestie dotyczące życia wspólnoty, rozwiązuje trudne przypadki związane z sumieniem. Pisze o zachowaniu wobec braci, wyjaśnia czym są wady i cnoty.
\end{abstract}

Keywords: Saint Basil the Great, monasticism, eastern monasticism, religious rules, monastic rules

Słowa kluczowe: Św. Bazyli Wielki, monastycyzm, monastycyzm wschodni, reguły zakonne, reguły monastyczne

\section{Wstęp}

Św. Bazyli reguły życia monastycznego, zebrał i opublikował w jednym dziele, które $\mathrm{w}$ tradycji bizantyjskiej nosi nazwę Asketikon. Dzieło to bywa nazywane również Regutami monastycznymi, chociaż nie jest to tytuł oryginalny. Asketikon został ułożony w formie pytań i odpowiedzi, powiązanych z sobą tak, że tworzy jedno zwarte dzieło. Posiadał on dwa różne wydania.

Pierwsze z nich zawierało 203 pytań i odpowiedzi, będących owocem pracy św. Bazylego wśród wspólnot pontyjskich w latach 360-370. Dla członków tychże wspólnot wygłaszał on mowy, udzielał odpowiedzi na nurtujące ich problemy. Pierwsze wydanie nosiło nazwę Mały Asketikon (łac. Asceticon Parvum), aby odróżnić go od późniejszej rozszerzonej wersji. Ukazał się on w 368 roku. Do dzisiejszych czasów nie zachował się żaden jego grecki rękopis, a jedynie przekład łaciński Rufina, oraz fragmenty w języku syryjskim ${ }^{1}$.

Drugie wydanie było poszerzone i nosiło nazwę Wielkiego Asketikonu. Ukazało się ono około roku 377, przedstawiając najbardziej dojrzały etap cenobityzmu w opracowaniu św. Bazylego. Wzbogacony on został o nowe pytania i odpowiedzi. Złożony był z dwóch części nazywanych „regułami dłuższymi i krótszymi”.

Reguły dłuższe stanowią pierwszą serię pytań i odpowiedzi, zawierającą obszerny wykład zasad i norm ogólnego życia we wspólnocie. Są tam omówione podstawowe reguły życia duchowego takie jak: miłość, wyrzeczenia, posłuszeństwo oraz główne problemy w kwestii organizacji

1 Zob. Św. Bazyli Wielki, Pisma ascetyczne, t. 2, reguły dłuższe, reguły krótsze, przekład i opracowanie Ks. J. Naumowicz, Kraków 1995, s. 14. 
wspólnoty, jak chociażby: kryteria przyjęć kandydatów, cenobityzm, rola przełożonych, praca i modlitwa ${ }^{2}$.

Reguły dłuższe poprzedza wstęp, który zawiera wezwanie do gorliwości w życiu ascetycznym. Św. Bazyli we wstępie pisze: oto teraz czas upragniony, oto teraz dzień zbawienia (2 Kor 6,2) Teraz jest czas pokuty, potem nastapi czas wynagrodzenia, teraz jest czas trudu, potem nadejdzie czas zapłaty. Teraz Bóg jest pomocnikiem tych, którzy nawracaja się ze złej drogi, potem będzie strasznym i nieomylnym sędziq ludzkich czynów, słów i myśli. Teraz doświadczamy Jego cierpliwości, potem poznamy Jego sprawiedliwy sąd (...) każdy otrzyma według swoich uczynków ${ }^{3}$. Pisze również o posłuszeństwie przykazaniom. Mówimy zaś, że pragniemy Królestwa niebios, ale nie troszczymy się o to, co jest potrzebne do osiagniecia. Nie podejmujemy żadnego trudu dla wypetnienia przykazań Chrystusa, a zamierzamy, w próżności naszej duszy, osiagnąc te sama chwałe, co ci, którzy trudzili się a do przelewu krwi, walczac przeciwko grzechowi $i^{4}$. Zauważa przy tym: my uważamy, że spetniwszy jedno z przykazań nie powinniśmy już oczekiwać kary za nasze inne przekroczenia, ale spodziewać się nagrody za dobry uczynek. Święty mówi, że wszystkie przykazania są ze sobą powiązane i kiedy naruszamy jedno z nich, występujemy przeciwko wszyswtkim pozostałym ${ }^{5}$.

\section{Reguły dłuższe}

Reguły dłuższe dzielę według pism ascetycznych, przełożonych i opracowanych przez Ks. J. Naumowicza ${ }^{6}$. Cztery pierwsze pytania mówią o miłości, miłości do Boga i bliźniego.

Pierwsze pytanie dotyczy porządku i kolejności Bożych Przykazań. Św. Bazyli odnosi się tu do rozmowy Chrystusa z uczonym w Piśmie o największe przykazanie (Mt 22,36). Hierarcha odpowiada za tekstem Ewangelii, że sam Bóg ustalit więc porzadek w swych przykazaniach określajac, iż pierwszym i największym jest przykazanie miłości Boga, drugim (...) dopetniajacym pierwsze i zależne od niego - przykazanie dotyczące miłości bliźniego ${ }^{7}$.

O miłości do Boga Biskup pisze, iż nie jesteśmy w stanie się jej nauczyć, tak jak nie uczymy się od nikogo cieszyć światłem lub życiem. Nikt przecież nie uczył nas miłości do matki, która nas wykarmiła i wychowała. $Z$ natury człowiek pragnie dobra, dlatego pożąda rzeczy pięknych. Piękne i godne miłości jest tylko to co dobre. Bóg jest dobrem. Wszystko pożąa dobra - wszystko wiec pragnie Boga ${ }^{8}$.

O miłości do bliźniego Święty poucza, że nakazano miłować bliźniego jak siebie samego, ale mówi również, iż

\footnotetext{
Tamże, s. 20.

Żywot i pisma świętego Bazylego Wielkiego, wyd. Orthdruk, Białystok, s. 20 .

4 Tamże, s. 20.

Tamże, s. 21.

Zob. Św. Bazyli Wielki, Pisma ascetyczne, t. 2, reguły dłuższe, reguły krótsze, przekład i opracowanie Ks. J. Naumowicz, Kraków 1995, s. 20-22.

7 Żywot i pisma świętego Bazylego Wielkiego, Białystok, Wyd. Orthdruk, s. $27-28$.

Zob. Tamże, s. 28
}

otrzymaliśmy od Boga zdolność wypełniania tego przykazania. Bazyli odwołuje się do następujących słów ewangelisty Jana: Przykazanie nowe daje wam, abyście się wzajemnie miłowali (J 13,34). Po tym wszyscy poznaja, żeście uczniami moimi, jeśli będziecie się wzajemnie mitowali (J 13,35). Św. Ojciec łączy ze sobą te dwa przykazania taki w sposób, iż dobro uczynione bliźniemu uważa jako wyświadczone Bogu. Pierwsze przykazanie, według niego prowadzi do wypełnienia drugiego, i na odwrót, ponieważ kto miłuje Boga będzie miłował bliźniego. W dalszej części odwołuje się do słów Zbawiciela: to jest moje przykazanie, abyście się wzajemnie miłowali, tak jak Ja was umitowałem (J 15,12). Tak więc, miłujący bliźniego wypełniają przykazanie miłości względem siebie. Hierarcha za wzór do naśladowania podaje dwa przykłady. Pierwszy ze Starego Testamentu ukazuje na postać Mojżesza, który okazywał miłość względem swoich braci oraz drugi z Nowego Testamentu, apostoła Pawła, który przez wstawiennictwo za braci, prosił o odłączenie od Chrystusa, ponieważ chciał się stać jak On wykupem za braci (Rz 9,3).

Oprócz miłości, w życiu monastycznym niezbędna jest również bojaźń Boża, z niej wypływająca. Św. Bazyli podkreśla, że pierwsze wychowanie dla nowicjuszy, powinno odbywać się przez bojaźń Bożą. Powołując się na słowa Salomona: poczatkiem madrości jest bojaźń Boża (Prz 1,7), zwraca uwagę, aby dzięki obfitości darów Bożych nie stała ona się przyczyną potępienia, gdy bracia bedą niewdzięczni dla swoich dobroczyńców.

W dalszej części Ojciec kapadocki pisze o unikaniu rozproszenia myśli. Zaznacza, że jeżeli nasz umysł błąka się, to przez to nie możemy zachować miłości do Boga i bliźniego. Kapadocyjczyk pisze, kto chce iść za Bogiem powinien pozbyć się przywiązania do życia, którego może dokonać poprzez zerwanie ze starymi obyczajami. Mówi, że powinniśmy troskliwie strzec naszego serca, by nie przydarzyło nam się rozproszenie myśli o Bogu lub splamienie widmem rzeczy złudnych pamięci o Jego cudowności $i^{9}$ Z powyższego wynika, że prawdziwa miłość do Boga i bliźniego jest możliwa tylko wówczas, gdy ukształtujemy w sobie bojaźń i będziemy potrafili zwalczyć rozproszenie myśli.

Szóste pytanie jest dalszą kontynuacją rozważań o miłości w kontekście innych cnót, oraz mówi o potrzebie oderwania się od świata, w celu uniknięcia rozproszenia umysłu. Hierarcha odpowiada, że pomocne jest zamieszkanie w odosobnieniu, od tych ludzi, którzy nie przestrzegają i lekceważą Boże przykazania. Ponieważ mieszkanie wśród nich jest szkodliwe i zgubne dla osoby trwającej w ascezie. Św. Bazyli zaleca, aby naszych oczu lub uszu nic nie pobudzało do grzeszenia $i$ abyśmy nie zdajac sobie $z$ tego sprawy, nie przyzwyczaili się do grzechu, a ponad to, by nie pozostawaly w naszej duszy - na nasza zgube i zatracenie (...) byśmy mogli gorliwie trwać na modlitwie należy przede wszystkim odejść w miejsce odosobnione ${ }^{10}$.

O życiu we wspólnocie święty poucza, że jest ono pod wieloma względami pożyteczniejsze niż anachoretyzm,

\footnotetext{
9 Tamże, s. 37.

10 Tamże, s. 40
} 
ponieważ nikt nie jest samowystarczalny, kiedy chodzi o potrzeby ciała. Ze względu na miłość Chrystusa nie jest dozwolone czerpanie korzyści jedynie dla samego siebie. W życiu w samotności trudno jest rozpoznać popełniony grzech, ponieważ nie ma nikogo, kto by udzielił upomnienia i porad służących poprawie. W wspólnocie łatwiej jest wypełniać przykazania, niż w pojedynkę.

Biskup stoi na stanowisku, że jednostka nie jest zdolna przyjąc wszystkich duchowych darów, gdyż Duch udziela się każdemu według głębi jego wiary. We wspólnym życiu dar udzielany jednemu staje się zarazem wspólnym darem tych, którzy z nim żyją ${ }^{11}$.

Dla grzesznika żyjącego we wspólnocie łatwiej jest zerwać z grzechem, kiedy postępuje zgodnie z wskazówkami braci. Życie w odosobnieniu pociąga za sobą inne niebezpieczeństwa. Pierwszym z nich jest zadowolenie z siebie. Hierarcha ostrzega, iz mnich pustelnik może dojść do przekonania, że osiągnął już stan doskonałości w wypełnianiu przykazań. Na sam koniec autor reguł przywołuje fragment Dziejów Apostolskich: Wszyscy stanowili jedna dusze i jedno serce, nikt nie mówit, że cokolwiek jest jego własnościa, wszystko bowiem mieli wspólne (Dz 4,32), jako wzór życia cenobitycznego.

Kolejne pytania (8 i 9) dotyczą kwestii „wyrzekania się," jako najwyższego wyrazu miłości. Św. Bazyli swoją odpowiedź opiera w tym miejscu na następujących tekstach Ewangelii: jeśli ktoś chce pójść za Mna, niech się zaprze samego siebie, niech weźmie krzyż swój i niech idzie za Mna (Mt 16,24), oraz: Tak wiec nikt $z$ was, kto nie wyrzeka sie wszystkiego, co posiada nie może być moim uczniem (Łk 14,33). Kapadocki Hierarcha zauważa, że powinniśmy przede wszystkim wyrzec się szatana i namiętności ciała, odrzucając bezwstyd. Należy wszelkie przywiązanie do rzeczy świętych, które stają się przeszkodą na drodze ku zbawieniu. Proces ten rozpoczyna się od porzucenia rzeczy zewnętrznych, takich jak: bogactwo, próżna chwała, towarzystwo ludzi, przywiązanie do przedmiotów. Za przykład osób, które wyrzekły się wszystkiego, święty podaje apostołów Jana, Jakuba, Mateusza i Pawła.

Św. Ojciec poucza, że kto opuszcza własna rodzine nie powinien pozostawić lekkomyślnie swoich dóbr, lecz zadbać o staranne nimi rozporzadzanie ${ }^{12}$. Przestrzega przed tym, iż powierzenie ich krewnym jak i osobą nieznanym nie jest bezpieczne.

Dalszą cześć reguł dłuższych stanową porady praktyczne takie jak: warunki przyjęcia do wspólnoty, nauka o wstrzemięźliwości, obowiązki, którym są poddani przełożeni wspólnot i braci, praca, modlitwa oraz leczenie.

Pytania od 10 do 15 traktują o ogólnych warunkach przyjęcia do wspólnoty. W tej kwestii Bazyli odpowiada, że ryzykownym jest odrzucenie tych, którzy przychodzą do Boga, powołując się przy tym na słowa Ewangelii św. Mateusza: Przyjdźcie do Mnie wszyscy, którzy utrudzeni i obciążeni jesteście, a ja was pokrzepię (Mt 11,28). Dlatego też mówi o konieczności poznania życia nowicjusza przed jego

\footnotetext{
11 Tamże, s. 43.

12 Tamże, s. 50.
}

wstąpieniem do klasztoru. Jeżeli żył on przykładnie, wówczas należy mu udzielić doskonalszych pouczeń. W przeciwnym wypadku należy poddać doświadczeniu, by ocenić ich charakter celem upewnienia się, czy nie sa niezdecydowani i zmienni w swych postanowieniach ${ }^{13}$. Autor reguł wzywa by nie tracić nadziei, lecz starać się nakłonić te osoby do podjęcia ćwiczeń duchowych, tak aby z czasem można było ich postępowanie uznać za rozstrzygające w podjęciu decyzji. Jeżeli w tym postępowaniu wyrobiona zostanie stałość, wówczas należy ich przyjąć bez żadnej obawy do wspólnoty. W przeciwnym wypadku można narazić na szkodę całą wspólnotę. Kapadocki Biskup zauważa: istnieje zaś jeden, wspólny dla wszystkich sprawdzian polegający na przekonaniu się, czy kandydaci sa na tyle pokorni, że nie wstydza się wykonywać nawet najbardziej poniżajacych czynności $i^{14}$. Dla osoby, która spieszy się z osiągnięciem pokory święty nakazuje nałożenie zadania uchodzącego za poniżające w oczach ludzi. Należy zwrócić uwagę czy dana osoba w pełnym przekonaniu pragnie stać przed Bogiem.

O człowieku pragnącym wstąpić do klasztoru, a będącym w związku małżeńskim Hierarcha mówi: tych, którzy sa złączeni matżeństwem i przystępuja do takiej jak nasza forma życia, należy zapytać czy czynia to za obopólna zgo$d a^{15}$. Stosując się do słów apostoła Pawła w Liście do Koryntian, że żaden z małżonków nie rozporządza własnym ciałem (1 Kor 7,4), zwraca on uwagę, że usilna modlitwa $\mathrm{w}$ połączeniu $\mathrm{z}$ wytrwałym postem sprawia, że $\mathrm{w}$ takim człowieku zwycięża zamiar prowadzenia życia w czystości.

Św. Bazyli zwraca również uwagę, aby nowicjusze ćwiczyli się w milczeniu, dając tym samym dowód swojego opanowania poprzez trzymanie języka na wodzy. Jednocześnie pobierając nauki w spokoju i bez roztargnień od tych, którzy mądrze operują słowem. Dlatego milczenie należy zachowywać nieustannie, poza wyjątkiem, gdy konieczność przerwania jest związana $\mathrm{z}$ troską o własną duszę, lub jest potrzebą wykonywanego zadania.

Osoby starające się wystąpić ze wspólnoty, wyrzekając się swojego zobowiązania, powinny być uważane jako takie, które zgrzeszyły przeciwko Bogu, przed Którym i dla Którego zobowiązały się ślubem. Jak pisze Biskup: kto poświęcit się Bogu, a potem odszedt, przechodzac do innego rodzaju życia, stał się świętokradca, ponieważ wykradł siebie $i$ odebrał dar złożony Bogu ${ }^{16}$. Dlatego, dla takiego człowieka nie zostaną otwarte już bramy klasztorne. Wspomniana reguła obowiązuje do dnia dzisiejszego, gdyż opuszczenie klasztoru przez mnicha zawsze było i jest przez Kościół piętnowane, jako wyrzeczenie się Chrystusa.

Na pytanie o wiek kandydata wstępującego do klasztoru, święty powołuje się na słowa ewangelisty Marka: Pozwólcie dzieciom przychodzić do Mnie (Mk 10,14). Pisze również, że w każdym, nawet najmłodszym, wieku można przyjmować tych, co się zgłaszaja ${ }^{17}$. Dusza młodej osoby, według św. Bazylego, jest podatna na kształtowanie, de-

\footnotetext{
3 Tamże, s. 52.

14 Tamże, s. 53.

15 Tamże, s. 55.

16 Tamże, s. 56.

17 Tamże, s. 57.
} 
likatna i miękka jak wosk, przyjmując formę. Od samego początku należy nadawać jej kształt, poprzez ćwiczenia się we wszelkiej dobroci.

O przyjmowaniu ślubów życia w czystości Hierarcha pisze, że mogą być one złożone przez nowicjusza dopiero, gdy on sam o tym zdecyduje, a jego wybór będzie, wynikiem osobistego przekonania i rozeznania oraz będzie podjęty całkowicie świadomie. Kto pragnie życia w dziewictwie powinien to uczynić po poważnym rozważeniu dokonanym w samotności, by nie wydawało się, że przyjmujemy kogoś nagle i bez zastanowienia ${ }^{18}$.

Kolejne zagadnienie Ojciec kapadocki omawia w pytaniach od 16 do 21: Mówi się w nich o zachowaniu wstrzemię́liwości. Podkreślając jego znaczenie, autor przywołuje słowa apostoła Pawła, który wymienia: wstrzemięźliwość pośród owoców Ducha (Ga 5,23). Nic nie jest tak pomocne w poskromieniu ciała i braniu go w niewolę jak wstrzemięźliwość. Żywiołowość właściwa wiekowi młodzieńczemu i porywy namiętności hamowane sa przez wstrzemięźliwośćl ${ }^{19}$. Święty przywołuje przykład starotestamentowych proroków: Mojżesza, Eliasza i Daniela, jako osoby, które właśnie dzięki wstrzemięźliwości otrzymały Prawo, słyszały głos Boży i widziały Boga. Wstrzemięźliwość jednak, nie polega na całkowitym stronieniu od pokarmów, ponieważ byłoby to narzuconym wyniszczaniem życia, lecz powstrzymywanie się od przyjemności, postanowione dla pokonania pożadań ciała i mające na celu życie wiary ${ }^{20}$. O spożywaniu wszystkich potraw, Ojciec kapadocki mówi, że gdy zajdzie potrzeba należy spróbować każdej potrawy. Stosownie do potrzeb nowicjusza należy spożywać potrawy, proste i konieczne dla jego życia, unikając przesytu, powstrzymując się od przyjemności.

Miarą wstrzemięźliwości jest całkowite wyrzeczenie się wszystkiego, co prowadzi do zgubnej przyjemności $i^{21}$. Pod słowem "przyjemność" rozumie on spożywanie pokarmów, a jej służenie to czynienie z brzucha boga. Św. Bazyli zauważa, że nie powinniśmy pod pozorem wstrzemięźliwości starać się o pożywienie szczególnie wyszukane i drogie, przygotowujac potrawy $z$ wybornymi przyprawami $i^{22}$. Praktyka wstrzemię́́liwości zakłada odmawianie wszystkiego, co stanowi dla adepta przeszkodę, wyznacza również miarę językowi, stanowi zaporę dla oczu i uszu.

Święty mówiąc o wstrzemięźliwości, odnosi się także do powściągliwości w śmiechu. W sferze duchowości pozwalanie sobie na nadmierny i niepohamowany śmiech jest oznaką niepowściągliwości. Brak panowania nad swoimi emocjami jest oznaką, że rozum nie kontroluje lekkomyślności ducha. Pismo bowiem, zwykło nazywać śmiechem radość duszy i pogodny nastrój rodzacy się z dobrych czynów ${ }^{23}$. Powściagliwość jest wiec unicestwieniem grzechu wyzbywaniem się namiętności umartwianiem ciała aż do opanowa-

\footnotetext{
8 Tamże, s. 60.

19 Tamże, s. 61

20 Tamże, s. 62.

Tamże, s. 66

Tamże, s. 68.

Tamże, s. 63-64.
}

nia jego naturalnych skłonności i pragnień, jest poczatkiem zycia duchowego ${ }^{24}$.

O sposobie przyjmowania gości i wyżywienia św. Ojciec mówi, że próżna chwała i pragnienie podobania się ludziom oraz czynienie wszystkiego na pokaz jest zabronione chrześcijanom. Podkreśla, że nasze życie, ma jeden cel - chwałę Bożą, przywołując przy tym słowa apostoła Pawła z Listu do Koryntian: czy jecie, czy pijecie, czy cokolwiek innego czynicie, wszystko na chwałe Boża czyńcie (1 Kor10,31).

O zajmowaniu miejsca przy stole, Biskup nawołuje nas do pokory mówiąc, że Chrystus nakazał zajmować ostatnie miejsce również wtedy, gdy siadamy przy stole. Uczy aby dawać przykład ludziom świeckim, poprzez niewywyższenie się i zajęcie ostatniego miejsca.

Pytania dotyczące zakresu obowiązków przełożonego i braci zawarte są $\mathrm{w}$ dwóch seriach pytań. Pierwsza z nich rozpoczyna się od 25 a kończy na 31 pytaniu. Druga seria natomiast rozpoczyna się od pytania 43 a kończy się na 54 .

Św. Bazyli zauważa, że przełożony któremu została powierzona troska o wszystkich, niech przeto postępuje jak ten, kto musi zdać sprawe $z$ każdego osobno ${ }^{25}$. Obowiązkiem przełożonego wobec braci jest czuwanie nad ich duszami i troska o zbawienie każdego z nich, do takiego stopnia, iż gotowy będzie pójść za nich na śmierć.

Pisze również, że wszyscy bracia podlegający przełożonemu i chcący prowadzić życie według przykazań Bożych, nie powinni skrywać żadnych poruszeń duszy ani wypowiadać nieprzemyślanego słowa. Zauważa, że raczej maja obowiązek odkrywać tajniki serca przed tymi, którym powierzono troskę o to, by w sposób życzliwy i miłosierny zajmować się chorymi braćmi ${ }^{26}$. A przełożony powinien utwierdzić u braci, co zasługuje na pochwałę, a co na naganę, naprawić.

Przełożony powinien być dobrym przewodnikiem we wszystkim. W przypadku jednak gdy wspólnota podejrzewa go o uchybienie, powinna go napomnieć. Jeśli zasługuje on na skarcenie, to pożytek odniesie on a przez to i cała wspólnota. Św. Hierarcha pisze: skierujemy na właściwa drogę tego, który jest jakby modelem naszego życia ${ }^{27}$.

Zdaniem Bazylego, przełożony nie powinien się pysznić swoją godnością, żeby nie utracić błogosławieństwa Bożego, ażeby wbiwszy się $w$ pychę nie wpadt $w$ diabelskie potępienie $(1 \mathrm{Tm} 3,6)$. Powinien być przekonany o tym, że troska o wielu oznacza służenie wielu. W taki sposób osiągnie swój cel według słów Chrystusa: Jeśli ktoś chce być pierwszym, niech będzie ostatnim ze wszystkich i stuga wszystkich (Mk 9,35).

O przyjmowaniu posługi przełożonego święty uczy, iż bracia powinni przyjąć posługę ze strony osoby, która w braterskiej wspólnocie jest postawiona wyżej. Ponieważ prawdziwa pokora zakłada, że ktoś znaczniejszy jest gotowy do służenia, a niższy nie krępuje się tym, że jest obsługiwa-

\footnotetext{
24 Tamże, s. 64.

25 Tamże, s. 78.

26 Tamże, s. 80.

27 Tamże, s. 80-81.
} 
$n y^{28}$, przywołując tu przykład Chrystusa, który umył nogi apostołom. Pisze również, że poddany nie powinien się obawiać, że przez to naruszy ideał pokory, gdy będzie mu posługiwała osoba wyższa godnością.

Drugą cześć stanowią pytania od 43 do 54. Na pytanie dotyczące tego, jacy powinni być przełożeni oraz tego jak kierować braćmi, św. Ojciec powołuje się na nakaz apostoła Pawła, z Listu do Tymoteusza: bądź wzorem dla wiernych! (Tm 4,12). Za swoim pośrednictwem powinni prowadzić słabych do naśladowania Chrystusa i jako pierwsi praktykować pokorę, żeby stać się doskonałymi wzorami tej cnoty. Przełożony powinien cechować się łagodnością, pokorą, cierpliwością i miłosierdziem. Nie może przemilczeć popełnianych przez braci błędów. Ma obowiązek zważać na wszystko, co się dzieje, przewidywać, co przyniesie jutro, być zdolnym do walki z silnymi, znosić niemoc słabych, a wreszcie mówić i czynić to wszystko, co stuży doskonaleniu tych, którzy z nim żyją ${ }^{29}$. Tylko takiej osobie - jak mówi św. Bazyli - należy powierzyć stanowisko przełożonego.

Święty na pytanie, komu zezwalać na podróż i po powrocie o co pytać, odpowiada, iż można udzielić zezwolenia tylko dla tego brata, który uczyni to bez żadnej szkody dla własnej duszy i z korzyścią dla osób, które spotka na swej drodze. Po powrocie należy wypytać go o to, co robit, z jakimi ludźmi się spotykał, o czym z nimi rozmawiał, jakie byty jego myśli $i^{30}$.

Na pytanie o tym, że nie należy ukrywać przewinień, pisze, że powinny one być przedstawione przełożonemu przez samego winnego, lub przez tych braci, którzy się o tym dowiedzieli. Powołuje się tu na List do Koryntian: lepsza jest jawna nagana niż miłość tajona (1 Kor 15,56).

Ważnym elementem w życiu wspólnoty dla św. Bazylego są relacje między przełożonym a braćmi. Dlatego omawia on w swoich regułach kilka kwestii: kiedy można sprzeciwić się przełożonemu, w jaki sposób to uczynić, co zrobić $\mathrm{z}$ niepokornymi braćmi, w jaki sposób $\mathrm{z}$ nimi postępować? O nieprzyjmowaniu postanowień przełożonego, Hierarcha poucza, że jeżeli brat ma przeciwko swemu ihumenowi ważny powód, zgodny z Pismem Świętym, wówczas powinien on przeciwstawić się otwarcie lub na osobności wobec przełożonego. Gdyby jednak niektórzy trwali w niepostuszeństwie i czynili skrycie wymówki zamiast oświadczyć, co ich gnębi, niech będa wykluczeni $z$ braterskiej wspólnoty ${ }^{31}$. Mówi również, że nikt nie może mieszać się w zarządzenia przełożonego. Wyjątek stanowią bracia zajmujący wysokie miejsce w wspólnocie, obdarzeni mądrością i ci którzy są najbliżsi przełożonemu. Przełożony zaś sam powinien zwracać się do nich o radę w sprawach dotyczących wspólnoty.

Św. Bazyli pisząc o kwestiach relacji pomiędzy braćmi pisze, iż kwestie sporne należy pozostawiać przełożonemu. Jeśli chodzi o upominanie, ihumen nie powinien zwracać się do winnego pod wpływem silnej emocji, ponieważ napominanie w gniewie i złości nie uwalnia go od grzechu,

\footnotetext{
28 Tamże, s. 85.

29 Tamże, s. 108.

30 Tamże, s. 109.

31 Tamże, s. 113.
}

lecz oznacza popadanie samemu $w$ grzech. W chwili upominania powinien zastosować się on do słów apostoła Pawła: $\mathrm{z}$ łagodnością pouczać wrogo usposobionych $(2 \mathrm{Tm} 2,25)$.

Podobne kwestie rozpatrywane są w pytaniu 28, gdzie mowa jest o postawie, jaką powinni zachowywać bracia wobec osoby, która jest nieposłuszna we wspólnocie. Jeśli jeden $\mathrm{z}$ braci niechętnie okazuje posłuszeństwo przykazaniom Chrystusowym, uczy by wszyscy wraz z nim współcierpieli, porównując go do chorej części ciała, a przełożonego do lekarza, który powinien starać się uleczyć go z tej choroby. Mówi również, że osoba niezgadzająca się na leczenie, jakie stosuje ihumen, zaprzecza sama sobie, ponieważ nie chce iść za własną wolą i pozostaje w wspólnocie a przełożonego traktuje jak przewodnika.

Św. Bazyli o owocach pracy braci, którzy szemrają i popadają w pychę mówi, że nie mogą być stawiane na równi z tymi, którzy są pokornego serca i skruszonego ducha $a^{32}$. Należy również usuwać ze wspólnoty owoce pracy człowieka leniwego i szemrzącego.

Osobę opanowaną namiętnościami przełożony zobowiązany jest traktować tak, jakby leczył chorego. Słabości duszy nakazuje leczyć nawet surowymi metodami, których przykłady wymienia ${ }^{33}$. O tych, którzy podlegają leczeniu, Hierarcha pisze, że należy przyjmować kary nie obrażając się i nie odbierając jej, jako przemoc skierowaną przeciwko nim. Powinni oni odbierać ją, jako o troskę będąca oznaką miłosierdzia i chęcią pomocy w zbawieniu ich duszy.

To samo tyczy się wykonywania niepoprawnego rzemiosła. Kiedy uczniowie podczas pracy postępują niewłaściwie, powinni zostać upominani przez nauczyciela w cztery oczy poprawiając ich w sprawach, w których się mylili.

Święty mówi również, że prawidłowym jest, aby w określonym czasie i miejscu zwołać zebranie tych, którzy przewodzą klasztorom, ponieważ dzielą się wzajemnymi problemami każdej z wspólnot, z jakimi borykają się na co dzień. Wtedy dzięki osądowi wielu, ukaża się w wyraźnym świetle jakieś popetnione błędy, a to, co byto dobre, zostanie potwierdzone doświadczeniem wielu ${ }^{34}$.

Odpowiedzi dotyczące pracy i modlitwy w Regułach znajdują się w pytaniach od 37 do 42. Biskup uzasadnia konieczność pracy powołaniem się na słowa Jezusa Chrystusa: wart jest robotnik swej strawy (Mt 10,10). Mówi, że nie można uważać życia pobożnego za pretekst do lenistwa i unikania trudu, uważając je, jako wielkie zło. Przywołuje słowa Apostoła Narodów: kto nie chce pracować, ten niech też i nie je (2 Tes 3,10), św. Bazyli zauważa, że dla każdego potrzebny jest pokarm i dlatego każdy powinien pracować według swoich sił i możliwości. Podczas modlitwy natomiast, powinniśmy się starać przebłagać Boga za dobrowolne, niedobrowolne i nieświadome grzechy popełnione słowem, uczynkiem i myślą.

Hierarcha mówi, że należy wybierać prace, nienaruszające spokoju i ładu życia wspólnoty, lecz jednocześnie

\footnotetext{
32 Tamże, s. 83

33 Zob. Tamże, s. 116.

34 Tamże, s. 118.
} 
nie powinny one doprowadzić do niestosownego i szkodliwego obcowania mężczyzn i kobiet ${ }^{35}$. Św. Ojciec wymienia również rzemiosła, które należy wykonywać w wspólnocie. Mnisi powinni zajmować się tkaniem, szewstwem, murarką, stolarką i kowalstwem, ale najważniejszą pracą jest praca w polu, ponieważ przynosi wielki pożytek dla wspólnoty.

Swięty przestrzega przed sprzedawaniem wytworów swej pracy i odbywaniem podróży. Będzie to $z$ większym pożytkiem dla wzajemnego budowania się i dla zachowania ścistego porzadku $w$ codziennym życiu ${ }^{36}$. Jeżeli jednak jest to niemożliwe to należy udać w większej liczbie braci do miejsc lub miast gdzie żyją pobożni ludzie.

$\mathrm{Na}$ temat jarmarków, odbywających się z okazji świąt religijnych Bazyli pisze: Pismo mówi nam wszakże, że zajmowanie się handlem $w$ miejscach poświęconych męczennikom nie jest dla nas stosowne ${ }^{37}$. Podczas świąt, chrześcijanie nie powinni mieć innych motywów, jak tylko pragnienie oddawania się gorliwej modlitwie.

O postepowaniu samowolnym i posłuszeństwie, mówi, że mnich, który wyrzeka się siebie i własnej woli, nie powinien czynić tego, co chce, ale to co mu polecono. Ten kto samowolnie wybiera własne zajęcie, staje się przyczyna swej zguby: przede wszystkim dlatego, że sztuka tego, co mu się podoba, następnie dlatego, że wybiera prace kierując się pragnieniem chwaly ludzkiej, nadzieja na zysk lub innym tego rodzaju uczuciem, albo też podejmuje pracę łatwiejsza z lenistwa i niedbalstwa ${ }^{38}$.

Biskup zauważa, iż żaden $\mathrm{z}$ braci nie powinien pracować, aby służyć własnej potrzebie, lecz by wypełnić przykazania Chrystusa, Który powiedział: Byłem głodny, a daliście Mi jeść (Mt 25,35). Celem przyświecającym każdemu z braci podczas pracy, musi być chęć pomocy ubogim. O nastawieniu ducha, święty przywołuje tu słowa proroka Jeremiasza: przeklęty mąż, który pokłada nadzieję w człowieku $i$ który w ciele upatruje swa siłe, a od Boga odwraca swe serce (Jr 17,5). W ten sposób, pokładanie nadziei jedynie na samym sobie i drugim człowieku jest oznaką oddalenia się od Boga.

Ostatnie pytane zawarte w regułach dłuższych dotyczy korzystania ze środków medycznych oraz tego czy ich używanie jest zgodne z pobożnym życiem. Św. Bazyli mówi, że Bóg dał dla człowieka różnego rodzaju sztuki, aby były pomocą jego słabej naturze. Wymienia wśród nich m.in.: rolnictwo i tkactwo. Mówiąc, że podobnie ma się rzecz z murarstwem i medycyną. Stwierdza również, że to Bóg, który kieruje calym naszym życiem, podarowat nam - jako wzorzec uzdrawiania duszy - medycynę, która usuwa nadmiar i uzupetnia braki $i^{39}$. Jeżeli konieczne jest posłużenie się medycyną, wówczas należy pamiętać, że zdrowie i choroby nie są zależne jedynie od medycyny, lecz jak sam pisze winniśmy odwoływać się do jej pomocy na chwałę Boga i traktowali ja jako znak troski o duszę ${ }^{40}$. Św. Bazyli mówi, że nie na-

\footnotetext{
35 Tamże, s. 100.

36 Tamże, s. 101.

3 Tamże, s. 101.

8 Tamże, s. 103.

9 Tamże, s. 118.

4 Tamże, s. 119.
}

leży wiec całkowicie unikać sztuki leczenia ani też pokładać $w$ niej całej nadziei. Jak jednak korzystamy z umiejętności uprawiania ziemi, chociaż u Boga wypraszamy zbiory, jak pozostawiamy ster prowadzacemu okręt, choć modlimy sie do Boga o wybawienie nas od niebezpieczeństwa morza, tak też uciekamy się do lekarza, kiedy rozum nam to podpowiada, nie zaprzestajac nadziei w Bogu ${ }^{41}$.

\section{Reguły krótsze}

Reguły krótsze stanowią drugą część Wielkiego Asketikonu. Znane są nam dwie redakcje pytań krótszych. Pierwsza pochodząca z Pontu zawiera 286 pytań i odpowiedzi, drugi natomiast, z Cezarei posiada ich 318. Św. Bazyli wyjaśnia w nich szczegółowe kwestie dotyczące życia wspólnoty, za pomocą odpowiedzi na pytania związane z konkretnymi sytuacjami z życia mniszego. Rozwiązuje trudne przypadki związane z sumieniem, wyjaśnia znaczenie wad i cnót, pisze o zachowaniu wobec braci. Udziela również odpowiedzi na pytania teologiczne i kwestie biblijne. Duża ilość pytań dotyczy problemów życia duchowego, związanych $\mathrm{z}$ poszukiwaniem praktycznych rozważań. Jak pisze ks. Naumowicz: Reguly krótsze zawieraja rzeczywiste pytania postawione Bazylemu i sa jedynie prostym „zbiorem ustnych, improwizowanych odpowiedzi, spisanych przez stuchaczy tak, jak zostaly powiedziane"42.

Pytania i odpowiedzi wchodzące w skład drugiej części Wielkiego Asketikonu zostały ułożone tematycznie. J. Gribomont podzielił owe reguły na dwanaście części ${ }^{43}$. Wyjątek stanowią dwa pierwsze pytania, o charakterze wstępnym. Pierwsze dotyczy wartości Pisma Świętego. Hierarcha w odpowiedzi pisze, że każdy potrzebuje Ducha, jako dobrego i świętego przewodnika, aby zostać skierowanym na drogę prawdy w myślach, słowie i uczynku ${ }^{44}$. Drugie dotyczy zobowiązań monastycznych. Święty przywołuje słowa z Ewangelii Mateusza (Mt 16,24) i odwołuje się do pytania $8 \mathrm{w}$ regułach dłuższych oraz pierwszej serii reguł krótszych.

Tematem pierwszej serii jest pokajanie i nawróce$n i e^{45}$. Biskup odpowiada na pytania dotyczące nawrócenia grzeszników, jak należy czynić pokutę za każdy grzech a jak postępować z osobami jej nieprzynoszącymi. Odpowiada na pytania, co czeka osoby obiecujące poprawę i o tych, którzy bronią grzeszników. Pisze również o owocach nawrócenia a także o tym jak znienawidzić grzech,.

Tematem serii drugiej jest sam grzech ${ }^{46}$. Św. Bazyli udziela odpowiedzi dotyczących myśli, skąd pochodzi ich nieuporządkowanie oraz jak je naprawić, jak również o pochodzeniu nieprzyzwoitych myśli podczas snu. Wyjaśnia co oznaczają pojęcia takie jak: obelga, odmowa, samolubstwo,

\footnotetext{
41 Tamże, s. 123.

42 Św. Bazyli Wielki, Pisma ascetyczne, t. 2, dz. cyt., s. 23.

43 Zob. Tamże, s. 23.

44 Tamże, s. 214

45 W skład serii pierwszej wchodzą pytania od 3 do 20. Zob. tamże, s. $216-231$.

46 W skład serii drugiej wchodzą pytania od 21 do 84 . Zob. tamże, s. $231-275$.
} 
nieczystość, rozwiązłość, jakie są cechy złości i oburzenia, podstęp i złośliwość. Jak powstrzymywać się od gniewu i zachłanności. Pisze o różnicach pomiędzy goryczą, złością, gniewem i zapalczywością. Zajmuje się kwestiami dotyczącymi jedzenia, i tych braci, którzy szukają w nim przyjemności. Wspomina o tych, którzy podczas posiłków zachowują się niewłaściwie. Porusza również takie kwestie jak na przykład: w jaki sposób należy karcić braci, którzy są gorliwi, a jak tych, którzy są obojętni, a jak radzić sobie z tymi którzy są niesforni i cechują się wybuchowym charakterem.

Tematem serii trzeciej jest ubóstwo ${ }^{47}$. Św. Hierarcha udziela odpowiedzi na pytania, czy mogą mnisi posiadać coś własnego we wspólnocie. Wyjaśnia ponadto pojęcie troski doczesnej.

Tematem serii czwartej są obowiązki przełożonych ${ }^{48}$, $\mathrm{w}$ jakim duchu przełożony powinien rozdzielać zadania i z jakim usposobieniem powinien udzielać nagany. Jak postępować w stosunku do żebrzących, przychodzących z zewnątrz, oraz z tymi braćmi, którzy opuszczają wspólnotę. Mówi również o tym, czy wypada, aby ihumen mógł rozmawiać z mniszką o sprawach wiary podczas nieobecności przełożonej, i czy wypada, aby rozmawiał często $\mathrm{z}$ ihumenią. Mówi również o sposobach spowiedzi sióstr.

Tematem serii piątej jest posłuszeństwo ${ }^{49}$. Św. Ojciec odpowiada na pytania dotyczące tego: jak i komu należy być posłusznym, jak również o wzajemnym posłuszeństwie i jego granicach. Doradza również jak zapobiegać namiętnościom, co czynić z bratem, który nie przyjmuje polecenia, ale ich nie wykonuje, lub je odrzuca całkowicie, czy brat może opuścić wspólnotę bez powiadomienia przełożonego i uchylać się od ciężkiej pracy, czy też jak należy postępować $\mathrm{z}$ osobą, która się smuci z powodu, iż nie pozwolono mu czynić tego, co on sam jest w stanie dobrze wykonywać.

Tematem serii szóstej jest post ${ }^{50}$. Hierarcha odpowiada na pytania dotyczące jego przestrzegania, radzi jak opierać się zachłanności w jedzeniu oraz porusza temat ludzi, którzy podczas posiłków szemrają. Poucza także, iż strudzony człowiek nie powinien szukać pociechy za wykonany trud. Pisze o tym, jak należy postępować z braćmi spóźniającymi się na wspólne posiłki, czy należy powstrzymywać się na jakiś czas od pokarmu, czy można pościć i czuwać więcej $\mathrm{z}$ własnej woli.

Tematem serii siódmej jest praca fizyczna ${ }^{51}$, którą mają wykonywać bracia we wspólnocie. Mówi, że w warsztacie powinien przebywać sam pracownik, by w ciszy i spokoju wykonywać swoją pracę. Pisze, że nie należy przyjmować pieniędzy bez wiedzy przełożonego pod karą należną złodziejowi. Mówi o traktowaniu narzędzi, którymi się posłu-

\footnotetext{
47 W skład serii trzeciej wchodzą pytania od 85 do 95. Zob. tamże, s. 275-283.

48 W skład serii czwartej wchodzą pytania od 96 do 113. Zob. tamże, s. 283-295.

49 W skład serii piątej wchodzą pytania od 114 do 125 . Zob. tamże, s. 295-304.

50 W skład serii szóstej wchodzą pytania od 126 do 140. Zob. tamże, s. 304-314

51 W skład serii siódmej wchodzą pytania od 141 do 156. Zob. tamże, s. $314-322$
}

guje i jak należy postępować, gdy się je zgubi, oraz co należy czynić, gdy ktoś spełnia posługę i pracuje ponad swoje siły.

Tematem serii ósmej jest wewnętrzne usposobienie ${ }^{52}$. W tej części św. Bazyli udziela rad dotyczących tego z jakim usposobieniem należy służyć Bogu, oraz z jak przyjmować karę, $\mathrm{z}$ jakim nastawieniem powinien postępować mnich żywiący urazę, i jaką powinien okazać pokorę. Mówi również o miłości bliźniego, usposobieniu podczas wypełniania przykazań, jak ma się zachować młodszy brat, który ma za zadanie nauczania starszego brata. Uczy o prawidłowym traktowaniu gorliwych braci czyniących dobro i tych, którzy są mniej gorliwi, z jaką bojaźnią i przekonaniem duszy powinniśmy uczestniczyć w Ciele i Krwi Chrystusa, o tym, czy wypada rozmawiać podczas śpiewania psalmów, z jaką gorliwością i sercem należy wypełniać przykazania Pana o miłowaniu bliźniego według tych przykazań, o tym, kim są nieprzyjaciele, których mamy miłować, i wreszcie o usposobieniu duszy i uwadze, jaką powinniśmy słuchać tego, co jest czytane podczas posiłku.

Tematem serii dziewiątej jest stosunek do krewnych i rodziny ${ }^{53}$, oraz pytania dotyczące Pisma Świętego ${ }^{54}$. Bazyli pytany o stosunek do krewnych, udziela odpowiedzi na pytania jak postępować z rzeczami, które dostał od swoich bliskich, jak ich traktować podczas odwiedzin, a jak postępować, gdy rodzina namawia na powrót do domu. Mówi również o współczuciu dla rodziców, pragnąc ich zbawienia.

W pytaniach dotyczących Pisma Świętego, udziela odpowiedzi na pytania dotyczące radości w Panu, to czym jest pokora i w jaki sposób można ją osiągnąć. Następnie odpowiada na pytania dotyczące chwały Bożej, o okazywaniu pomocy nowo wstępującym do wspólnoty. Udziela rad dotyczących rozproszenia myśli. Mówi jak stać się uczestnikiem w Duchu Świętym oraz pisze kim są ubodzy w duchu. Udziela odpowiedzi na temat godziwego odzienia, mówi o miłości Bożej, jaka jest jej miara, jak ją osiągnąć, jakie są jej przejawy. Wyjaśnia różnice pomiędzy łaskawością a dobrocią. Udziela odpowiedzi, kim jest czyniący pokój. Mówi również o myślach, o tym czy należy wyjawiać je innym.

Tematem serii dziesiątej są zagadnienia moralne wynikające $\mathrm{z}$ tekstów bibliii ${ }^{55}$. Św. Bazyli odpowiada napytania dotyczące skarbca dobrego i złego. Mówi, że pod skarbcem dobrym są ukryte cnoty ku chwale Bożej i na odwrót. Wyjaśnia sens znaczeń szerokiej bramy i drogi, oraz ich przeciwieństwie, mówiąc, że wąska brama prowadzi do życia, zaś szeroka do zguby. Tłumaczy znaczenie zdania: $W$ miłości braterskiej bądźcie nawzajem miłującymi się serdecznie (Rz 12,10), pozostawcie to pomście (Rz 12,19) i miłość nie dopuszcza się bezwstydu (1 Kor 13,5). Mówi o godności i sprawiedliwości oraz talentach i jak je mnożyć. Wyjaśnia różni-

\footnotetext{
52 W skład serii ósmej wchodzą pytania od 157 do 186. Zob. tamże, s. 323-345.

53 Pierwsza cześć serii dziewiątej stanowią pytania od 187 do 190. Zob. tamże, s. 345-348.

54 Druga cześć serii dziesiątej stanowią pytania od 191 do 238. Zob. tamże, s. 348-380.

55 W skład serii dziesiątej wchodzą pytania od 239 do 278. Zob. tamże, s. $381-418$.
} 
ce pomiędzy ubóstwem a biedą, oraz czym jest szczerość. Mówi o sensie określeń: „synowie niedowiarstwa” i „dzieci gniewu”. Wyjaśnia, w jaki sposób ktoś staje się głupim dla świata.

Serie jedenasta i dwunasta ${ }^{56}$ zawierają pytania, które zostały uszeregowane bez żadnego porządku tematycznego. Św. Bazyli mówi w nich o znaczeniu słów: śpiewajcie psalmy rozumnie (Ps 47,8), oraz pisze o czystości serca. Mówi o pokucie, grzechu i rozproszeniu. Wyjaśnia różnice pomiędzy próżnością a szukaniem własnej chwały oraz o tym jaka jest granica posłuszeństwa.

56 W skład serii jedenastej i dwunastej wchodzą pytania od 279 do 318 . Zob. tamże, s. 418- 453.
Powyższy artykuł jest próbą przedstawienia i analizy praw życia monastycznego spisanych przez św. Bazylego Wielkiego, jak również przedstawienie duchowości bazyliańskiej w nich zawartej. Jego reguły są wykładnią najdoskonalszego modelu życia monastycznego według, których do dnia dzisiejszego kierują się wspólnoty Kościoła Wschodniego. Należy również zwrócić uwagę na to, że stały się one podstawą i filarem dla kreowania się różnych reguł monastycznych w Kościele Zachodnim.

Uniwersalność norm bazyliańskich może równie dobrze służyć dla każdego człowieka, nie będącego ascetą, jako podstawy życia rodzinnego, pojmując rodzinę jako małą wspólnotę a rodziców jako jej przełożonych który troszczy się o swoje dzieci.

\section{Bibliografia}

\section{Źródła}

Pismo Święte Starego i Nowego Testamentu, Wydawnictwo Pallottinum, Warszawa - Poznań 1965.

Św. Bazyli Wielki, Listy, przełożył W. Krzyżaniak, PAX 1972.

Św. Bazyli Wielki, Pisma ascetyczne, t 1, wstęp do zarysu ascezy, o sądzie Bożym, o wierze, reguły moralne, przekład i opracowanie Ks. J Naumowicz, Kraków 1994.

Św. Bazyli Wielki, Pisma ascetyczne, t 2, reguły dłuższe, reguły krótsze, przekład i opracowanie Ks. J Naumowicz, Kraków 1995.

Bazyli Wielki, Żywot i pisma świętego Bazylego Wielkiego, Białystok 2001.

Полное собрание творений святых отцов Том 1. Святитель Василий Великий. Творения. Книга 3, Moskwa 2008.

Полное собрание творений святых отцов Том 2. Святитель Василий Великий. Творения. Книга 4, Moskwa 2012.

\section{Literatura przedmiotu}

Aghiorgoussis M. Bp., Monastycyzm, [w:] Prawosławie światło wiary i zdrój doświadczenia, Lublin 1999.
Doroszkiewicz B. Ks., Monastycyzm bizantyjski od IX do połowy XV wieku, Białystok 2009.

Doroszkiewicz W. Archim., Rola monastycyzmu we wspótczesnym świecie, Elpis, rocznik XI (XXII), zeszyt 19-20(32-33), Białystok 2009.

Filimoniuk M. ks., Kuźmiuk J., Monastycyzm szkic historyczny, Białystok 2000

Kanior M., Monastycyzm, [w:] Encyklopedia Katolicka, t 13, Lublin 2009.

Kostiuczuk J. Bp, Monastycyzm wschodni, [w:] Życie monastyczne w Rzeczypospolitej, Białystok 2001.

Kowalski J.W., Świat mnichów i zakonów, Warszawa 1987.

Никольский Т. К. Прот., Пособие к Изучению Устава Богослужения Православной Церкви, Moskwa 2008.

Sacharow S. Arch., Święty Sylwan z Góry Atos, przełożył ks. P. Nikolski, Białystok 2007.

Sołowjew A. Ks., Ojcowie cerkwi o starcostwie i monastycyzmie, Hajnówka 1997.

Żurek A. Ks., Święty Bazyli Wielki, WAM, Kraków 2009. 